\title{
West Nile Encephalitis and Its Characteristics in Childhood
}

\author{
Meltem Karabay ${ }^{1,2,}$; Aziz Ogutlu $^{2}$; Gokcen Ozturk ${ }^{2}$; Ertugrul Guclu $^{2}$; Oguz Karabay $^{2}$ \\ ${ }^{1}$ Department of Pediatrics, Faculty of Medicine, Sakarya University, Sakarya, Turkey \\ 2 Department of Infectious Diseases and Clinical Microbiology, Faculty of Medicine, Sakarya University, Sakarya, Turkey \\ *Corresponding Author: Meltem Karabay, Department of Infectious Diseases and Clinical Microbiology, Faculty of Medicine, Sakarya University, Sakarya, Turkey. E-mail: drkarabay@gmail.com
}

Received: July 1, 2014; Accepted: November 30, 2014

Keywords: Child; West Nile Virus; Fever

\section{Dear Editor,}

West Nile virus (WNV) is a member of the family flaviviridae. Culex mosquitoes and birds are playing crucial role in the spread of WNV. It can also spread through blood transfusions, organ transplants and from mother to baby in the course of breastfeeding (1). WNV was first isolated in a village of Uganda and many epidemics related to this disease have been reported ever since. However, as of this date, great epidemics have been reported in Africa, Europe, Russia and Israel (2). Although various data were given in epidemiologic studies in Turkey, we could reach only one case report from child age group in our country (3). With this letter, for the first time, we aimed to draw attention to the issue by defining WNV infection and its characteristics in children. We present five cases diagnosed West Nile Infection who were admitted with meningo-encephalitis. Cerebrospinal fluid findings and clinical properties of the five cases are summarized in Tables 1 and 2.

Epidemiological studies show that the disease is increased during summer. The nature of the disease is closely related with mosquitos, all of our cases were seen in August-September. WNV is a mosquito borne disease with epidemics in regions where mosquitoes are common between May and October. In our cases, the average age of five children was 9.2. The diagnosis of these five children was established detecting IgM positivity in blood sample taken within 14-18 days after onset of symptoms. The disease has been detected in serological analysis performed in our country. WNV occurs generally with encephalitis symptoms in children under one and adults over 60 years. In a different study in the same region in 2010, encephalitis was detected in five cases in an epidemic. Average age was 64.6. These five cases presented with fever, headache, nausea, vom- iting, muscle pains, and consciousness (4). Neuroinvasive WNV disease is generally in the form of meningitis, encephalitis or acute flaccid paralysis. Extrapyramidal symptoms, ataxia, optic neuritis, myelitis and the signs of cranial nerve involvement are the neurological symptoms that occur less frequently. Encephalitismeningo-encephalitis by itself is more frequent than meningitis (5).

Rash frequency is 50\%. Rash is typically localized in chest, back and arms, and it has maculo-papular character. Rash is a crucial prognostic indicator for severe disease and death (6). While WNV is symptomatic progressive in elders, it is generally asymptomatic progressive in young. WNV was detected in 1478 children in USA between 1999 and 2007 (7). There was neck stiffness in three cases, Kernig and Brudzinski positivity in two cases. Although rash in WNV encephalitis is reported in various sources, we observed it in only one case in our study. In this case, rash appeared on legs and it was of maculo-papular characteristic. In CSF (Cerebrospinal fluid) analysis of WNV encephalitis, protein may be normal or slightly high. CSF protein, CSF glucose and CSF cell count of the cases was between $20-200 \mathrm{mg} / \mathrm{dL}$, 49$66 \mathrm{mg} / \mathrm{dL}$ and $0-500 \mathrm{~mm}^{3}$ respectively. Hence, children with WNV encephalitis resented with typical signs of aseptic meningitis.

According to our experience, WNV clinical signs of encephalitis started suddenly, and headache and fever were present in all children. WNV must be taken into consideration in suspicious cases in beginning of autumn and mid-summer in provinces located on the migration route of birds. In summer, before diagnosing aseptic meningitis in a child with headache, encephalitis and fever, WNV testing should be done.

Copyright (C) 2015, Growth \& Development Research Center. This is an open-access article distributed under the terms of the Creative Commons Attribution-NonCommercial 4.0 International License (http://creativecommons.org/licenses/by-nc/4.0/) which permits copy and redistribute the material just in noncommercial usages, provided the original work is properly cited. 
Karabay M et al.

\begin{tabular}{|c|c|c|c|c|c|}
\hline & Case 1 & Case 2 & Case 3 & Case 4 & Case 5 \\
\hline CSF Protein, $\mathrm{Mg} / \mathrm{dL}$ & 20 & 30 & 20 & 200 & 100 \\
\hline CSF glucose, $\mathrm{mg} / \mathrm{dL}$ & 66 & 55 & 65 & 56 & 49 \\
\hline Blood glucose, mg/dL & 154 & 109 & 145 & 111 & 98 \\
\hline CSF Chloride, $\mathrm{mmol} / \mathrm{L}$ & 117 & 114 & 117 & 126 & 125 \\
\hline CSF albumin, mg/dL & 15 & 20 & 10 & 190 & 70 \\
\hline CSF Cell count, $\mathrm{mm}^{3}$ & 0 & 110 & 0 & 10 & 500 \\
\hline Parameter & Case 1 & Case 2 & Case 3 & Case 4 & Case 5 \\
\hline Age, $y$ & 10 & 16 & 3 & 13 & 4 \\
\hline Leukocyte count $10^{9} / \mathrm{L}$ & 11000 & 9200 & 8000 & 8400 & 6300 \\
\hline Fever & + & + & + & + & + \\
\hline Headache & + & + & + & + & + \\
\hline Vomiting & + & + & - & - & + \\
\hline Neck stiffness & + & + & - & + & - \\
\hline Kernig & + & + & - & - & - \\
\hline Brudzinski & + & + & - & - & - \\
\hline Rash & + & - & - & - & - \\
\hline
\end{tabular}

\section{References}

1. Hayes EB, Komar N, Nasci RS, Montgomery SP, O'Leary DR, Campbell GL. Epidemiology and transmission dynamics of West Nile virus disease. Emerg Infect Dis. 2005;11(8):1167-73.

2. Artsob H, Gubler DJ, Enria DA, Morales MA, Pupo M, Bunning ML, Dudley JP, et al. West Nile Virus in the New World: trends in the spread and proliferation of West Nile Virus in the Western Hemisphere. Zoonoses Public Health. 2009;56(6-7):357-69.

3. Tapisiz A, Emiralioglu N, Vural O, Ozcan B, Oznur N, Bedir T, et al The first report of West Nile virus infection in a child from Turkey. Turk J Pediatr. 2011;53(3):317-9.

4. Karabay O, Tuna N, Yahyaoglu, M. , Ozturk G. High cerebrospinal fluid protein level in West Nile virus encephalitis: report of five cases. Turkish J Med Sci. 2012;42(6):1142-6.

5. Nash D, Mostashari F, Fine A, Miller J, O'Leary D, Murray K, et al. The outbreak of West Nile virus infection in the New York City area in 1999. N Engl J Med. 2001;344(24):1807-14.

6. Pealer LN, Marfin AA, Petersen LR, Lanciotti RS, Page PL, Stramer SL, et al. Transmission of West Nile virus through blood transfusion in the United States in 2002. N Engl J Med. 2003;349(13):123645.

7. Lindsey NP, Hayes EB, Staples JE, Fischer M. West Nile virus disease in children, United States, 1999-2007. Pediatrics. 2009;123(6):e1084-9. 